\title{
Organization of the internal membrane system in the principal cells of the mouse epididymis after osmium impregnation
}

\author{
Marcelle-Anne FAIN-MAUREL, Aïda ABOU-HAÏLA, J. P. DADOUNE
}

Groupe d'Etude de la Formation et de la Maturation du Gamète Mâle (Laboratoires de Biologie Cellulaire et d'Histologie)

45, rue des Saints-Pères, 75270 Paris Cedex 06, France.

Summary. The ultrastructure of the principal cells of the mouse epididymis was studied using osmium impregnation techniques which have the advantage that the endoplasmic reticulum (ER) content displays a positive reactivity after glutaraldehyde fixation whereas the Golgi condensing vacuoles are negative.

In the proximal part (caput) of the epididymis, the Golgi apparatus formed a large supranuclear area filled with electronluscent secretory vacuoles while, in the medial (corpus) and distal (cauda) parts, dictyosomes were small and sparse with few secretory vacuoles. In all the principal cells of the caput, the supranuclear ER cisternae were heterogeneously impregnated. In the corpus and cauda, the ER appeared as an extensive continuous network of canaliculi and saccules which were fenestrated when surrounding mitochondria. The ER content was homogeneously stained but impregnation intensity varied from cell to cell. In the apex of the caput cells, numerous impregnated or electronluscent vesicles were seen in close apposition to the plasma membrane, while in the corpus and cauda some Golgi vacuoles and extensions of ER canaliculi were observed in the terminal webb region. Thus, in the epididymal caput, osmium impregnation suggested that two distinct secretory pathways were functioning continuously. The first corresponded to the transport of proteins to the cell membrane by the Golgi condensing vacuoles. The second might only affect the small impregnated vesicles of the ER, through which proteins bypassed the Golgi apparatus and were exported towards the lumen. In the corpus and cauda, the network organization of the ER and the association of fenestrated cisternae with mitochondria (also found in absorptive epithelial cells) supported the view of a predominant absorptive function in these epididymal parts.

\section{Introduction.}

It is well known that the mammalian epididymis secretes proteins and glycoproteins. The major secretory products which interact with the sperm surface are secreted in the distal caput regions although other parts of the epididymal duct may play a role (Moore, 1980 ; Lea and French, 1981 ; Vernon 
et al., 1982). In addition, this organ is able to absorb material coming from the testis via the rete testis fluid particularly at the level of the initial segment (Pelliniemi et al., 1981). However the cauda epididymis is also regarded as another region with high absorptive capacity (Moore and Bedford, 1979). Ultrastructural examination of the principal cells clearly shows the organelles involved in both the secretory and the absorptive functions but does not allow for visualization of the transfer pathways of macromolecules (Abou-Haila and Fain-Maurel, 1984). Osmium impregnation techniques appear to be a good tool for differentiating the endoplasmic reticulum from the Golgi apparatus which both play a role in the two functions. In the absence of aldehyde fixation only the Golgi saccules are impregnated by osmium (Friend and Murray, 1965), while after aldehyde fixation the content of both the Golgi and the endoplasmic reticulum cisternae is stained (Thiéry, 1979). In the present investigation, these techniques were used to study the internal membrane system in the principal cells of the mouse epididymis with emphasis on the secretory and absorptive functions.

\section{Materials and methods.}

Three male mice (Swiss OF1) about 3 months old were anaesthetized by intraperitoneal injection of chloral hydrate and the 2 epididymides were removed. The right epididymis was immersed (5 min) in a special glutaraldehyde solution $(0.1 \mathrm{M}$ veronal buffer $\mathrm{pH} 7: 63 \mathrm{ml} ; 0.1 \mathrm{M}$ trisodium citrate : $13.5 \mathrm{ml} ; 0.1 \mathrm{M}$ $\mathrm{CaCl}_{2}$ : $13.5 \mathrm{ml}$; glutaraldehyde $25 \%$ : $10 \mathrm{ml}$ ) (Thiéry, 1979; Bergeron and Thiéry, 1981). Small fragments from the five segments of the proximal part (Abou-Hailla and Fain-Maurel, 1984) and the medial and distal parts of the duct were cut out (Graph 1). The samples were quickly washed and post-fixed ( $2 \mathrm{~h}$, $4{ }^{\circ} \mathrm{C}$ ) in buffered $1 \%$ osmium tetroxide. The fragments of the same portions of the left epididymis were immediately fixed only in the second solution. Then, all the samples were rinsed in distilled water and submitted to impregnation in an aqueous $1 \%$ osmium tetroxide solution for 3 days at $37{ }^{\circ} \mathrm{C}$ with renewal of the solution every $12 \mathrm{~h}$. After impregnation, the tissues were dehydrated and embedded in Epon. Semi-thin sections were used for histological study. The ultra-thin sections stained with uranyl-acetate and lead citrate were examined in a Philips EM 300.

\section{PLANCHE I.}

Osmium impregnation after g/utaraldehyde fixation. Semithin sections observed without counter staining at the level of segment I (fig. 1, 2), II (fig. 3), III (fig. 4), IV (fig. 5), V (fig. 6) of the proximal part and the medial (fig. 7) and distal (fig. 8) parts of the epididymis.

Note the decreasing size of the Golgi and the progression towards the apical part of the cells from segments I to $\mathrm{V}$. In the medial and distal parts, cells are more or less impregnated. $\mathrm{G} \times 3300$ (fig. 1, 2) and 2400 (fig. 3-8). 



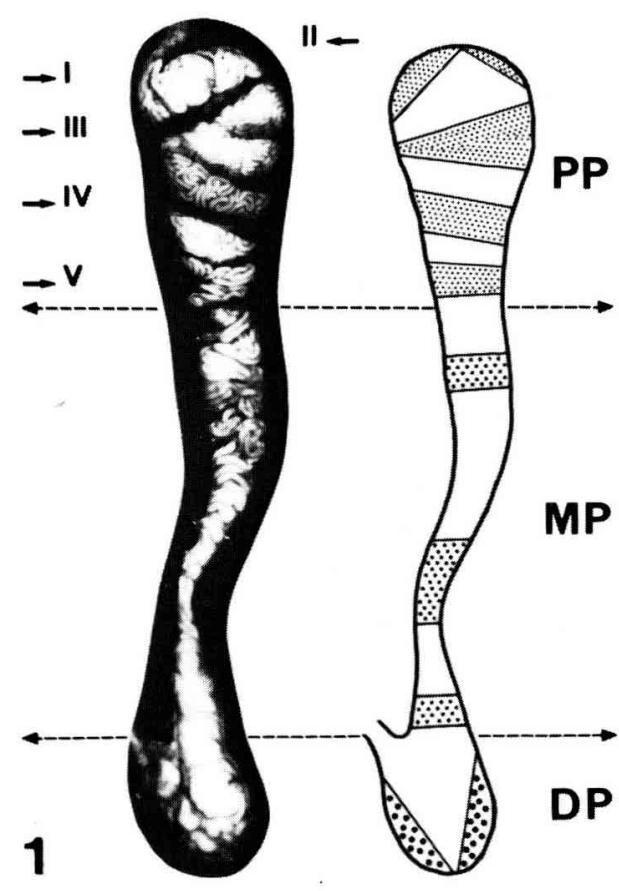

GRAPH 1. - Mouse epididymis showing the level of samples taken from the five segments of the proximal part (PP), the medial (MP) and distal (DP) parts.

\section{Results.}

On semi-thin sections, the osmium impregnation technique, performed either after or without aldehyde fixation, simultaneously stained the Golgi apparatus and endoplasmic reticulum in the different parts of the mouse epididymis. Golgi complex organization varied according to anatomical level whatever the fixation method. In the principal cells of the proximal part of the epididymis, it was composed of highly impregnated thick strands which bounded a large Golgi area (PI. I, fig. 1-6). In the medial and distal parts, it consisted of thin loosely coiled strands located in the supra-nuclear region of the cell (PI. I, fig. 7, 8).

After glutaraldehyde fixation, the infranuclear part of the principal cells from segment I was strongly impregnated (PI. I, fig. 1) and small dark granules, with varying degrees of staining, were found above the Golgi complex in the five segments of the proximal part of the duct (PI. I, fig. 1-6). In the medial (PI. I, fig. 7) and distal (PI. I, fig. 8) parts, a more or less impregnated network extended throughout the cytoplasm of a great number of cells.

\section{PLANCHE II}

Fig. 1. - Golgi impregnation after g/utara/dehyde fixation in segment /. G $\times 12000$.

Fig. 2. - Golgi impregnation without g/utaraldehyde fixation in segment /I/. Note the numerous small dense granules surrounding dictyosome cis-face. $\mathrm{G} \times 20000$.

Fig. 3. - Dictyosome impregnation after glutaraldehyde fixation in the medial part of the epididymis. $\mathrm{G} \times 20000$. 
Ultrastructural examination of the Golgi apparatus revealed that after or without glutaraldehyde fixation the cis-face saccules were always well impregnated along the duct while trans-face condensing vacuoles remained electronluscent (PI. II). These vacuoles exhibited a regular outline after glutaraldehyde fixation. In the proximal part of the epididymis, the cup-like Golgi apparatus contained many secretory vacuoles (PI. II, fig. 1). In segment III, in the absence of aldehyde fixation, the Golgi saccules were surrounded by numerous small ( $d<0.05 \mu \mathrm{m}$ ) dark granules scattered in the vicinity of the cis-face (PI. II, fig. 2). In the medial and distal parts, sparse small dictyosomes poor in secretory vacuoles were seen in the supranuclear part of the principal cells (PI. II, fig. 3).

Observation under the electron microscope confirms that the endoplasmic reticulum content of the principal cells of the proximal part was only impregnated after aldehyde fixation (PI. III). However the aspect of the stained material varied with the anatomical level of this region of the duct. The cup-like endoplasmic reticulum cisternae located under the nucleus in segment I were homogeneously and strongly impregnated (PI. III, fig. 1). The content of the vesicles, which filled the supranuclear region of all the principal cells in the first three segments of the epididymal caput, was heterogeneously stained and appeared to be composed of filamentous or granular dark material. Only the size of the vesicles increased from segment I (PI. II, fig. 2) to III (PI. II, fig. 3). On the contrary, in segments IV and $V$, the content of the endoplasmic reticulum cisternae, parallel to the long axis of the cells, was homogeneously stained but with varying intensity from cell to cell (PI. III, fig. 4). In the medial and distal parts of the epididymis, whatever the type of fixation, the endoplasmic reticulum was formed of a continuous network of canaliculi and saccules impregnated with features similar to those of cells in segments IV and $V$ (PI. IV, fig. 1, 2). When impregnated, the endoplasmic reticulum saccules surrounding mitochondria appeared to be fenestrated (PI. IV, fig. 2). However, in some cells where the endoplasmic reticulum was unstained, the perinuclear cisternae showed an osmium deposit.

In the proximal part of the epididymis, the apical part of the principal cells was devoid of terminal webb and filled with impregnated or electronluscent vesicles originating from endoplasmic reticulum or Golgi complex ( $\mathrm{Pl} . \mathrm{V}$, fig. 1). They were often in close apposition to the plasma membrane (PI. V, fig. 2, 3). In the cells of the medial and distal parts of the duct, some Golgi vacuoles and extensions of the endoplasmic reticulum network in contact with the apical plasma membrane were observed in the area of the terminal webb (PI. IV, fig. 1, 2).

The lytic structures consisted of multivesicular bodies containing osmiumimpregnated vesicles (PI. V, fig. 4) and residual bodies. Multivesicular bodies were particularly numerous in the apical regions of the cells from segment III and

PLANCHE III.

Osmium impregnation of the endoplasmic reticulum after glutaraldehyde fixation in the infranuclear (fig. 1) and supranuclear (fig. 2) region in segment $/$, in segment /II (fig. 3 ) and $\mathrm{V}$ (fig. 4). G $\times 13500$ (fig. 1), 16500 (fig. 2, 3) and 20000 (fig. 4). 
the medial and distal parts of the duct, while a large amount of residual bodies were present in segment $\mathrm{I}$.

\section{Discussion.}

The technique of osmium impregnation has been used to stain the Golgi apparatus in various cell types (Friend and Murray, 1965; Rambourg et al., 1974). In the Thiéry technique (1979), because of pre-fixation with glutaraldehyde, osmium black deposits occur on the endoplasmic reticulum as well as on the Golgi saccules, thus revealing the organization and relationships between these organelles. The non-impregnation of the endoplasmic reticulum observed in some cells can be linked to a functional difference rather to an artefact, since the next perinuclear cisternae and the Golgi apparatus, a fragile structure when an alteration process takes place, are well stained. Similarly, the faint or strong tracing of the endoplasmic reticulum in adjacent principal cells probably parallels cell activity phases, as has been shown for their enzyme activities (Abou-Haila and Fain-Maurel, 1984 ; Abou-Haila et al., 1985) or the secretory epithelial cells of the rat prostate where endoplasmic reticulum impregnation by osmium can be modified by hormonal factors (Beaudry-Lonergan et al., 1985). Osmium deposits in the prostate have been considered to be an indicator of the presence of secretory products. Thus, this technique may provide a valid test for cell function even if some structures such as ribosomes are lost in the process.

In the mouse epididymis, osmium impregnation with the Thiery technique (1979) highlights two types of endoplasmic reticulum organization. In the proximal part of the caput (segments I, II, III), the content of sparsely granulated vesicular cisternae which filled the cell supranuclear region, was heterogeneously impregnated. Identical staining was observed in all the principal cells of these epididymal segments. In the medial and distal parts of the duct, this technique revealed that the short, flattened endoplasmic reticulum saccules found in conventional electron microscopy procedures, were in fact made of a continuous network of canaliculi and saccules throughout the cytoplasm. In contrast to the heterogeneous osmium deposits distributed inside the cisternae in the proximal part, the content of the extensive network in the medial and distal parts, was homogeneously stained but staining intensity varied from cell to cell. Similar organization has been previously reported in the rat renal tubule (Bergeron and Thiéry, 1981) and the small intestine (Thiéry et al., 1983). Moreover, in these epididymal parts, a reaction product was also found in several cells after exposure to osmium without aldehyde fixation, suggesting that at least parts of this organelle may be reducing environment. On the other hand, the transitional zone (segments IV, V) between the proximal part of the caput and the medial and distal parts of the duct was clearly seen after use of Thiéry's technique. The endoplasmic

PLANCHE IV.

Osmium impregnation of the apical region of principal cells in the medial part without (fig. 1) or after glutaraldehyde fixation (fig. 2). G × 8200 (fig. 1) and 9200 (fig. 2). 
$+3$

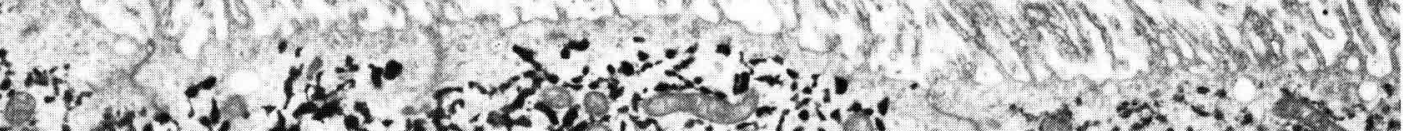

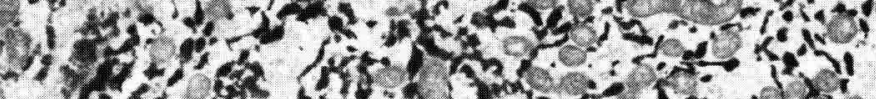

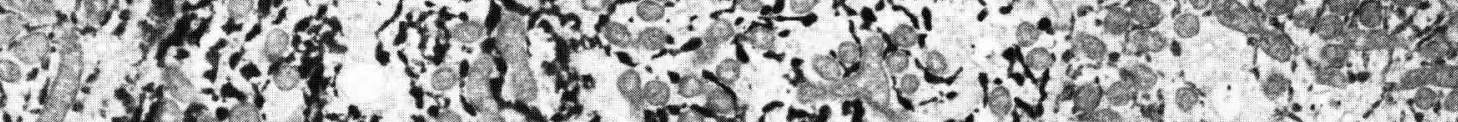

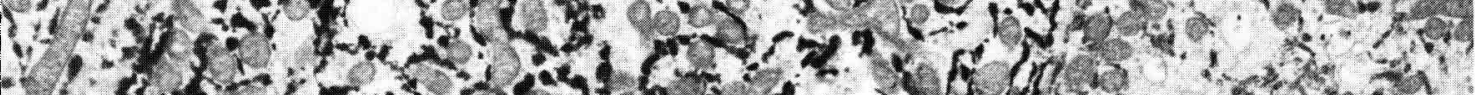

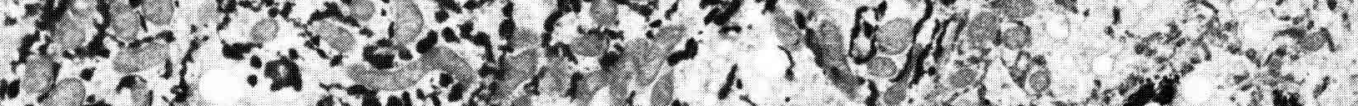

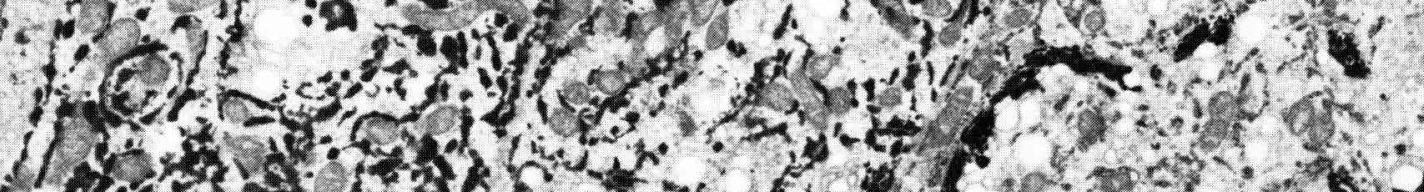

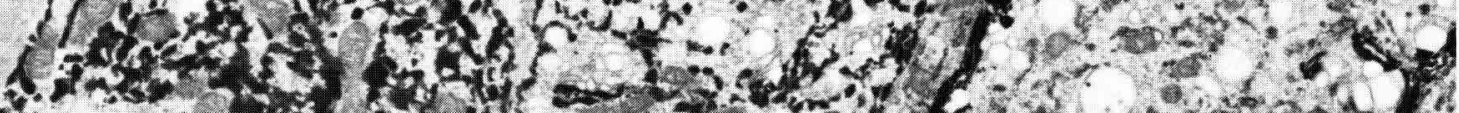
-

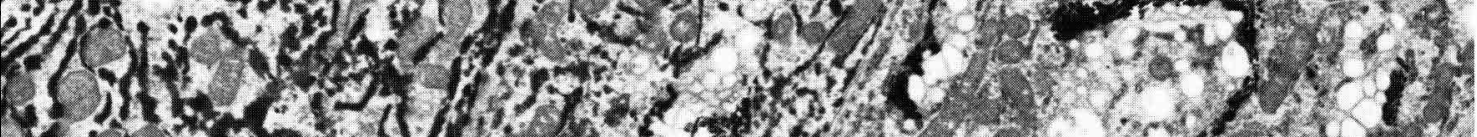
(4)

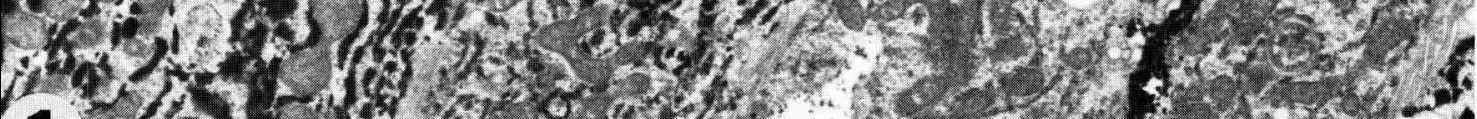

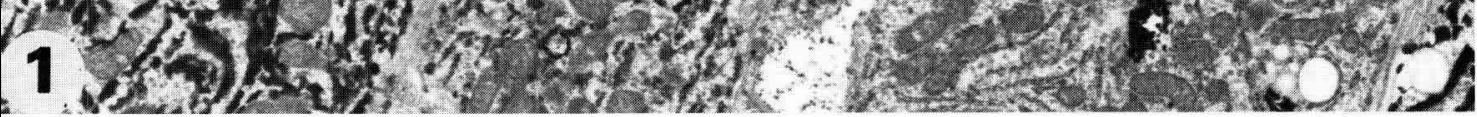

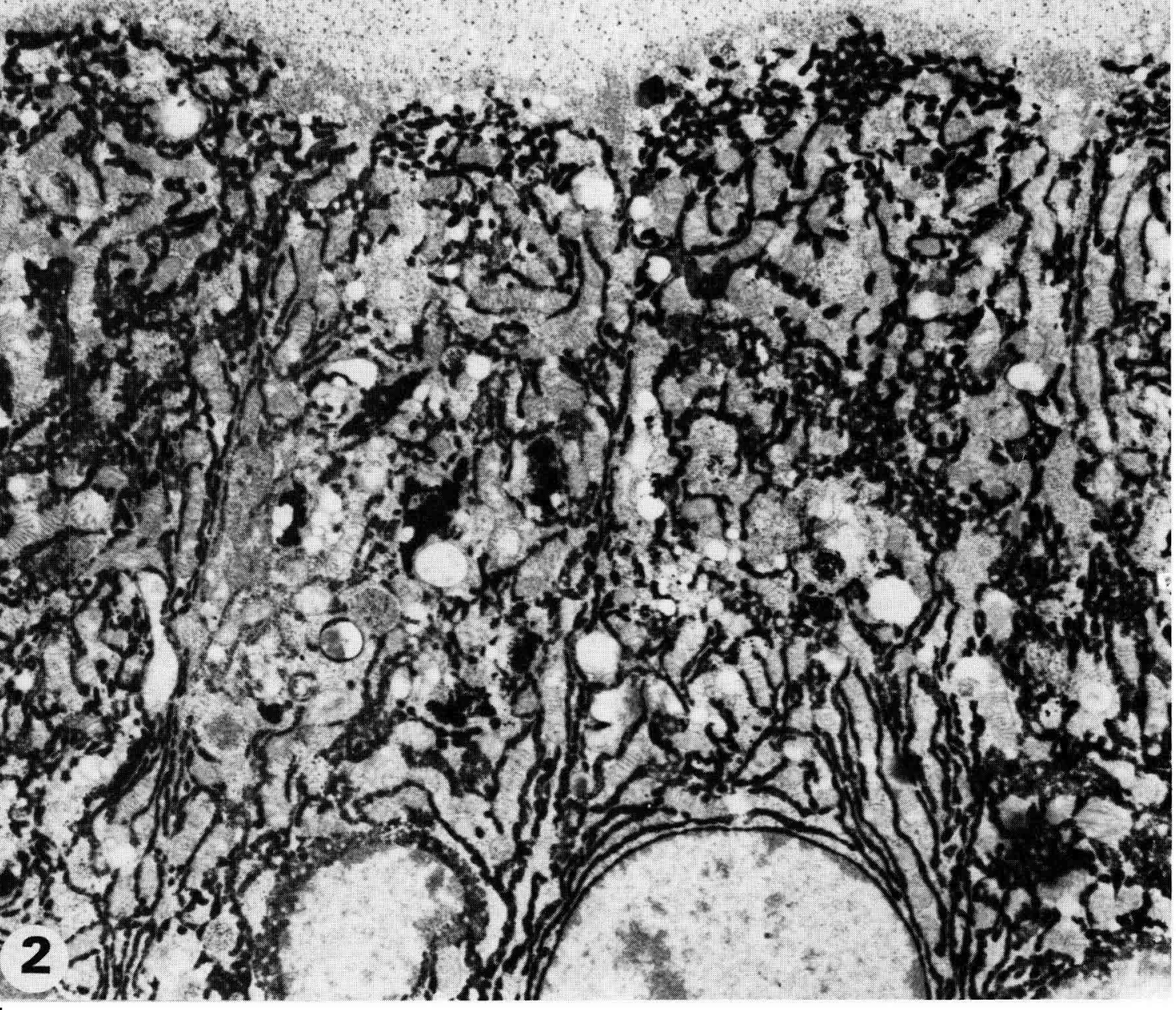


reticulum content appeared to be homogeneously impregnated as in the medial and distal parts, but the concentric pattern of the cisternae did not show any morphological communication. The parallel saccular profiles gave rise in the cell apex to vesicles similar to those observed in the first three segments of the epididymal caput.

These features confirm ultrastructural and metabolic findings which point clearly to a strict regionalization in the mouse epididymis (Abou-Hailla and Faint-Maurel, 1984, 1985, 1986 ; Abou-Hailla et al., 1985). They also underscore the particularities of segment III. In this segment characterized by a small diameter, spermatozoa storage, numerous and large apical multivesicular bodies (Abou-Hailla and Fain-Maurel, 1984) and a PAS-positive secretory product (Abe et al., 1982), small dark granules surrounding Golgi cis-face were seen when osmium impregnation was performed without aldehyde fixation. These reduced osmium particles have been previously described in mouse epididymis after osmium or silver impregnation (Yamaoka et al., 1983).

Numerous studies have documented the secretory and absorptive functions of the epididymal epithelium, but there is debate on which mechanisms are involved (for a review, see Cooper, 1986). Our observations suggest that osmium impregnation may prove useful for studying cell structure-function relationships in mouse epididymis.

In mammal epididymis, the cell's ability to synthesize proteins and glycoproteins is evidenced by an extensive rough endoplasmic reticulum and Golgi complex. However, in these cells which do not have storage granules, a secretory process along the duct has only been revealed by quantitative ultrastructural radioautography in the mouse (Fain-Maurel, 1987) or by electrophoresis in the mouse (Mboungou et al., 1987) and the rat (for a review, see Cooper, 1986) after radio-active aminoacid administration. Of particular interest to the present investigation is the fact that in the proximal part of the epididymis, the endoplasmic reticulum content always displayed a positive reaction to osmium whereas the Golgi condensing vacuoles were negative. Thus, it can be postulated that the two distinct secretory pathways described in segment 1 of the mouse epididymis (Fain-Maurel, 1987) may serve the same function in the other four segments of the proximal part. The topographical relations observed between the electronluscent or impregnated vesicles and the apical plasma membrane suggest that the newly-synthesized proteins were transferred into the lumen by the Golgi condensing vacuoles or impregnated endoplasmic reticulum vesicles bypassing the Golgi apparatus. The presence of these ultrastructural features suggests that in these constitutive (stimulus-independent) secretory cells, two distinct routes

PLANCHE V.

Fig. 1. - Osmium impregnation of the apical region of a principal cell in segment / after glutaraldehyde fixation. $\mathrm{G} \times 16500$.

Fig. 2, 3. - Close apposition to the plasma membrane of an impregnated vesicle in segment /I

(fig. 2) and an electron-luscent vacuole in segment /// (fig. 3). G × 40000 (fig. 2) and 54000 (fig. 3).

Fig. 4. - Impregnated multivesicular body in the supranuclear region of a principal cell in the distal part. $\mathrm{G} \times 32000$. 


\section{it \\ $x^{3}$}

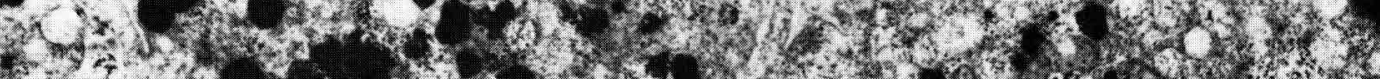

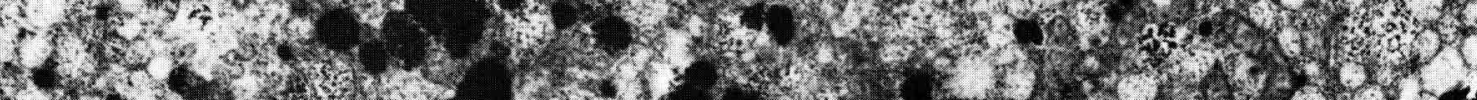

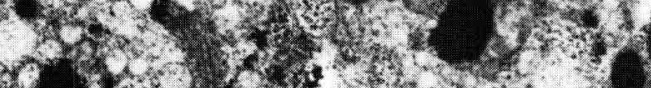

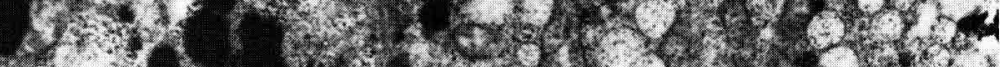

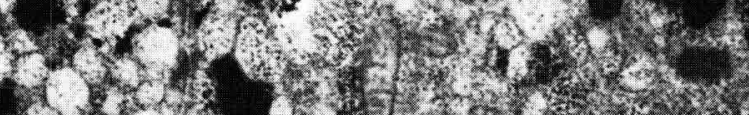

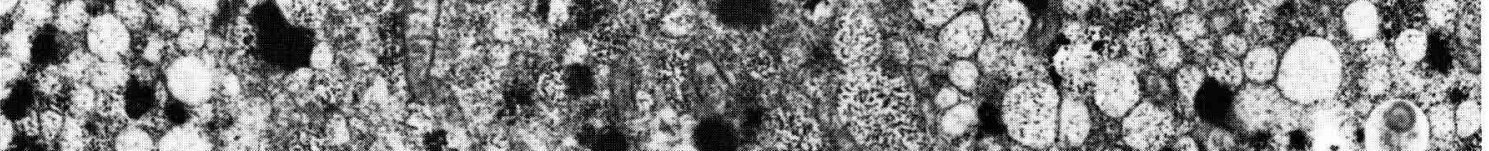

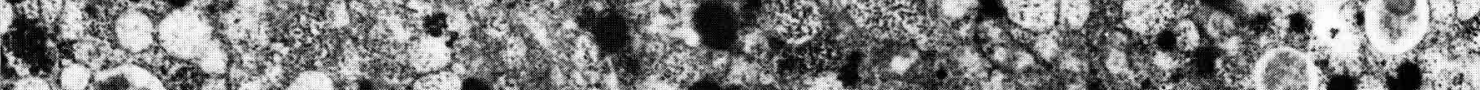

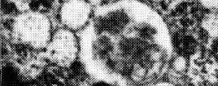

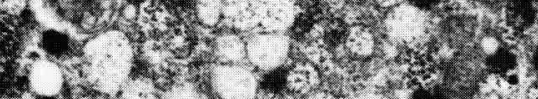

(3.

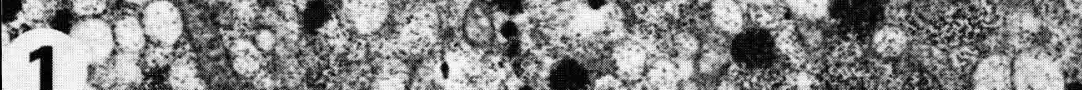

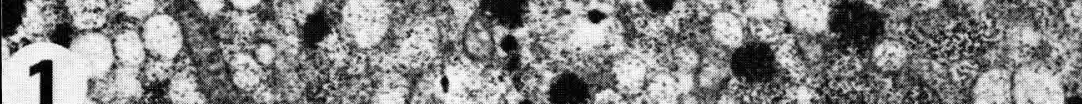

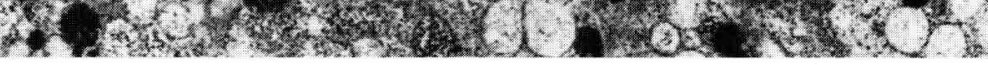

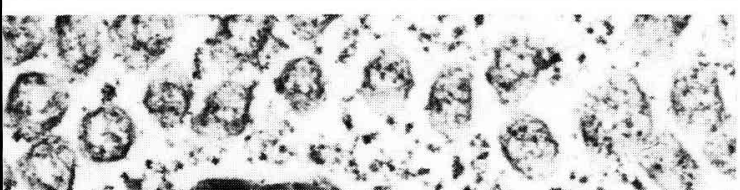

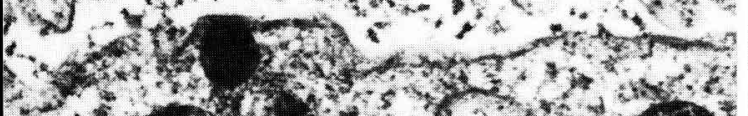

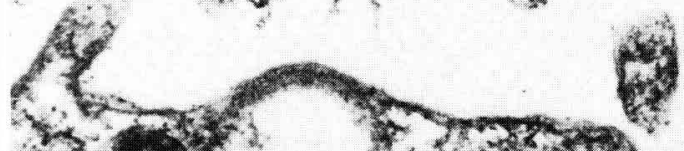

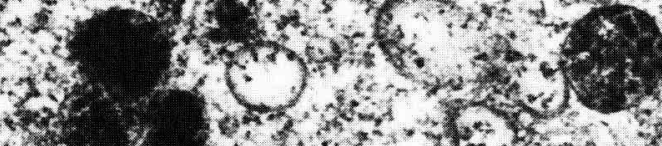

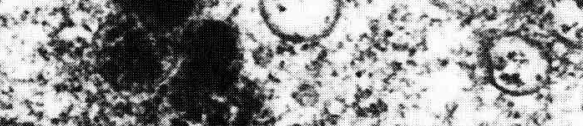

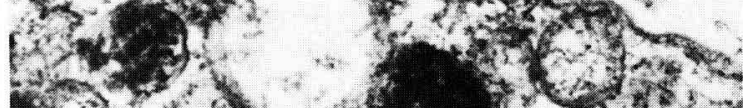

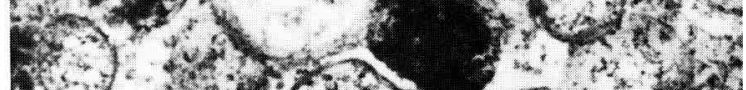
2.5.

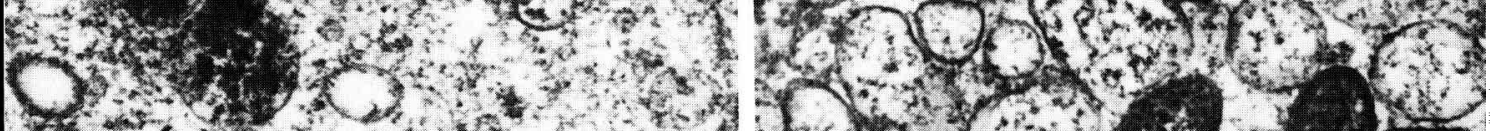

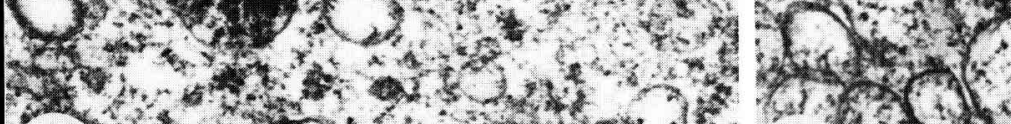

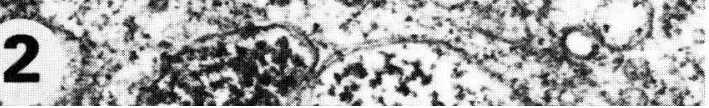

3 )

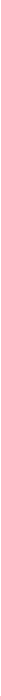


export a relatively different spectrum of proteins and/or glycoproteins. In prostatic cells, some secretory products of the endoplasmic reticulum also seem to be secreted directly into the lumen (Beaudry-Lonergan et al., 1985).

In the principal cells of the medial and distal parts of mouse epididymis, the observation of electronluscent Golgi vacuoles in the terminal webb region and of some extensions of the endoplasmic reticulum canaliculi in contact with the apical plasma membrane suggest that the two distinct constitutive export pathways visualized in the proximal part are also present in these parts. However, it seems unlikely that this extensive endoplasmic reticulum network, extending from the apex to the base of the cells, would only serve this goal. As in transport epithelia (Mollgaard and Rostgaard, 1978 ; Bergeron and Thiéry, 1981 ; Novikoff et al., 1983; Thiéry et al., 1983), the endoplasmic reticulum could be considered as a potential transcellular route. It has been shown that substances synthesized in the proximal part such as «sperm maturation antigen number 4 » in the mouse (Vernon et al., 1982) or the polypeptide complex 30-37 Kd in the rat (Olson and Hinton, 1985) are reabsorbed in the medial and/or distal parts of the epididymis. In addition, because of the relationships between endoplasmic reticulum fenestrated saccules and mitochondria in these parts, as shown in rat renal (Bergeron and Thiéry, 1981) and intestinal (Thiéry et al., 1983) cells, principal cells may assume a high fluid and electrolyte absorptive function in medial and distal parts of mouse epididymis.

Thus, osmium impregnation techniques provide good indication of the secretory function of the principal cells in the proximal part of the mouse epididymis and the absorptive function in the medial and distal parts. However, the functional segmentation of the duct is not as restrictive.

In the proximal part, mechanisms of fluid-phase and receptor-mediated endocytosis have been identified (Djakiew et al., 1985, 1986) and electron-dense tracers injected in the epididymal lumen found in apical vesicles and then in multivesicular bodies or lysosomes (Moore and Bedford, 1979). In the mouse, a conspicuous feature is the preferential location of residual bodies in segment I and multivesicular bodies in segment III although coated pits were observed in the five segments. Thus, specific absorptive mechanisms could vary with the different segments. On the other hand, a secretory process has been demonstrated by radioautography (Fain-Maurel et al., 1981) and electrophoresis (Mboungou et al., 1987) in the medial and distal parts of the epididymis.

$5^{e}$ Congrès de la Société d'Andrologie de Langue française, Paris, décembre 1987.

Acknowledgments. - The authors wish to thank Mrs. Georgette Hédouin for her excellent technical assistance, and the department of Electron Microscopy, CNRS, Université Paris $\mathrm{VI}$ for the pictures.

Résumé. Organisation du système endomembranaire dans les cellules principales de l'épididyme de souris après imprégnation osmique.

L'ultrastructure des cellules principales de l'épididyme de souris a été reconsidérée après mise en œuvre des techniques d'imprégnation osmique. L'imprégnation par l'osmium 
utilisée après fixation au glutaraldéhyde présente l'avantage de contraster le matériel ségrégé dans le réticulum endoplasmique (RE) alors que le contenu des vésicules de condensation de l'appareil de Golgi demeure transparent aux électrons.

Dans la partie proximale (tête) de l'épididyme, les dictyosomes délimitent dans la région supranucléaire une aire golgienne volumineuse riche en vésicules sécrétoires claires alors que, dans les parties médiane (corps) et distale (queue) du canal, les dictyosomes sont petits, pauvres en vésicules golgiennes et disséminés dans la région apicale des cellules. Dans toutes les cellules principales de la tête épididymaire, le contenu des citernes du RE supranucléaire est imprégné de manière hétérogène. Dans le corps et la queue, le RE forme un réseau continu de canalicules et de saccules qui, autour des mitochondries, apparaissent fenestrés. Son contenu est imprégné de manière homogène mais avec une intensité variable selon les cellules.

Dans la partie apicale des cellules principales de la tête de l'épididyme, de nombreuses vésicules claires ou imprégnées sont accolées à la membrane plasmique alors que, dans le corps et la queue, seules quelques vésicules golgiennes et de rares extensions des canalicules du RE sont visibles dans la région corticale. Ainsi, dans la tête épididymaire les résultats de l'imprégnation osmique suggèrent l'existence de deux voies sécrétoires distinctes fonctionnant de manière continue. La première correspond à la voie classique d'exportation des protéines par les vésicules golgiennes. La seconde impliquerait la libération directe dans la lumière du contenu osmiophile des petites vésicules du $R E$, court-circuitant le transit par l'appareil de Golgi. Dans le corps et la queue de l'épididyme, l'organisation en réseau du RE et l'association "citernes fenestrées-mitochondries » qui ont été antérieurement décrites dans des cellules épithéliales absorbantes, plaident en faveur de la prépondérance de la fonction d'absorption dans ces régions.

\section{References}

ABE K., TAKANO H., ITO T., 1982. Response of the epididymal duct in the corpus epididymis to efferent or epididymal duct ligation in the mouse. J. Reprod. Fert., 64, 69-72.

ABOU-HAILLA A., FAIN-MAUREL M. A., 1984. Regional differences of the proximal part of mouse epididymis. Morphological and histochemical characterization. Anat. Rec., 209, 197-208.

ABOU-HAIILA A., FAIN-MAUREL M. A., 1985. Postnatal differentiation of the enzymatic activities in the mouse epididymis. Int. J. Androl., 8, 441-458.

ABOU-HAİLA A., FAIN-MAUREL M. A., 1986. Electrophoretic characterization of mouse epididymal esterases in inbred lines and in a natural population. Andrologia, 18, 624-634.

ABOU-HAIILA A., DEUGNIER M. A., FAIN-MAUREL M. A., 1985. Histochemistry of oxidative metabolism in epididymal epithelium of mouse. Arch. Androl., 15, 1-10.

BEAUDRY-LONERGAN M., THIÉRY G., BERGERON M., 1985. Osmium impregnation of the endoplasmic reticulum correlates with the functional status of prostate secretory cells. Biol. Cell, 54, $181-186$.

BERGERON M., THIÉRY G., 1981. Three-dimensional characteristics of the endoplasmic reticulum of rat renal tubule cells, an electron microscopy study in thick sections. Biol. Cell, 42, 43-48.

COOPER T. G., 1986. The epididymis, sperm maturation and fertilisation. Springer-Verlag Berlin Heidelberg (ed.).

DJAKIEW D., BYERS S. W., LEWIS D. M., DYM M., 1985. Receptor-mediated endocytosis of alpha $_{2}$-macroglobulin by principal cells in the proximal caput epididymis in vivo. J. Androl., 6. 190-196.

DJAKIEW D., GRISWOLD M. D., LEWIS D., DYM M., 1986. Micropuncture studies of receptormediated endocytosis of transferrin in the rat epididymis. Biol. Reprod., 34, 691-699.

FAIN-MAUREL M. A., 1987. Cytophysiologie de l'épididyme chez les Mammifères. $5^{e}$ Congr. Soc. Andrologie de langue française, Paris, décembre 1987. 
FAIN-MAUREL M. A., DADOUNE J. P., ALFONSI M. F., 1981. High-resolution autoradiography of newly formed proteins in the epididymis after incorporation of tritiated amino-acids. Arch. Androl., 6, 249-266.

FRIEND D. S., MURRAY M., 1965. Osmium impregnation of the Golgi apparatus. Am. J. Anat., 117. $135-150$.

LEA O. A., FRENCH F. S., 1981. Characterization of an acidic epididymal glycoprotein secreted by principal cells of the rat epididymis. Biochim. Biophys. Acta, 688, 370-376.

MBOUNGOU J. R., JUNERA H. R., DADOUNE J. P., FAIN-MAUREL M. A., 1987. Caractérisation des protéines régionales de l'épididyme chez la souris pubère. $5^{e}$ Congr. Soc. Andrologie de Langue française, Paris.

MOLLGAARD K., ROSTGAARD J., 1978. Morphological aspects of some transporting epithelia suggesting a transcellular pathway via elements of endoplasmic reticulum. J. Membrane Biol., 40, 71-89.

MOORE H. D. M., 1980. Localization of specific glycoproteins secreted by the rabbit and hamster epididymis. Biol. Reprod., 22, 705-718.

MOORE H. D. M., BEDFORD J. M., 1979. Differential absorptive activity of epithelial cells of the rat epididymis before and after castration. Anat. Rec., 193, 313-328.

NOVIKOFFA. B., SPATER H. W., QUINTANA N., 1983. Transepithelial endoplasmic reticulum in rat proximal convoluted tubule. J. Histochem. Cytochem., 31, 656-661.

OLSON G. E., HINTON B. T., 1985. Regional differences in luminal fluid polypeptides of the rat testis and epididymis revealed by two-dimensional gel electrophoresis. J. Androl., 6, 20-34.

PELLINIEMI L., DYM M., GUNSALUS G. L., MUSTO N. A., BARDIN C. W., FAWCETT D. W., 1981. Immunological localization of androgen-binding protein in the male rat reproductive tract. Endocrinology, 108, 925-931.

RAMBOURG A., CLERMONT Y., MARRAUD A., 1974. Three-dimensional structure of the osmium impregnated Golgi apparatus as seen in the high voltage electron microscope. Am. J. Anat., 140, 27-46.

THIÉRY G., 1979. Colorations signalétiques électives sur coupes épaisses du réticulum endoplasmique, de la chromatine et des surfaces cellulaires libres des cellules animales. Biol. Cell, $\mathbf{3 5}$, 159-164.

THIERY G., GAFFIERO P., BERGERON M., 1983. Three-dimensional characteristics of the endoplasmic reticulum in the columnar cells of the rat small intestine: An electron microscopy study in thick sections. Am. J. Anat., 167, 479-493.

VERNON R. B., MULLER C. H., HERR J. C., FEUCHTER F. A., EDDY E. M., 1982. Epididymal secretion of a mouse sperm surface component recognized by a monoclonal antibody. Biol. Reprod., 26, 523-535.

YAMAOKA I., YAMAMOTO K., URABE N., NAGATANI Y., 1983. Osmium impregnation patterns of the Golgi complex in the epididymal epithelial cells of castrated and testosterone-injected mice. J. Cell Sci., 59, 71-79. 